\title{
Chemical defense of a soft-sediment dwelling phoronid against local epibenthic predators
}

\author{
Amy A. Larson ${ }^{1,3, *}$, John J. Stachowicz ${ }^{2}$ \\ ${ }^{1}$ Bodega Marine Laboratory, PO Box 247, Bodega Bay, California 94923-0247, USA \\ ${ }^{2}$ Section of Evolution and Ecology, University of California, Davis, California 95616, USA \\ ${ }^{3}$ Present address: Aquatic Bioinvasions Research and Policy Institute, Environmental Sciences and Resources, \\ Portland State University, PO Box 751 (ESR), Portland, Oregon 97207, USA
}

\begin{abstract}
Chemical defenses are thought to be infrequent in most soft-sediment systems because organisms that live beneath the sediment rely more on avoidance or escape to reduce predation. However, selection for chemical deterrence might be strong among soft-sediment organisms that are sessile and expose at least part of their body above the surface. The phoronid Phoronopsis viridis is a tube-dwelling lophophorate that reaches high densities $\left(26500 \mathrm{~m}^{-2}\right)$ on tidal flats in small bays in California, USA. We found that $P$. viridis is broadly unpalatable, and that this unpalatability is most apparent in the anterior section, including the lophophore, which is exposed to epibenthic predators as phoronids feed. Experimental removal of lophophores in the field increased the palatability of phoronids to predators; deterrence was regained after $12 \mathrm{~d}$, when the lophophores had regenerated. Extracts of $P$. viridis deterred both fish and crab predators. Bioassay-guided fractionation suggested that the active compounds are relatively non-polar and volatile. Although we were unable to isolate the deterrent metabolite(s), we were able to rule out brominated phenols, a group of compounds commonly reported from infaunal organisms. One predator, juvenile Scorpaenichthys marmoratus, consumed all $P$. viridis extracts and whole $P$. viridis. However, over time, this predator rejected phoronids when fed a diet that included 2 to 3 phoronids $\mathrm{d}^{-1}$. The broadly effective defenses possessed by phoronids, which may be unusual among soft-sediment invertebrates, may play a key role in allowing them to reach high densities.
\end{abstract}

KEY WORDS: Phoronopsis viridis - Chemical defense - Predation - Deterrent metabolites · Soft sediment $\cdot$ Regeneration $\cdot$ Palatability

Resale or republication not permitted without written consent of the publisher

\section{INTRODUCTION}

For sessile, hard-substrate organisms, many studies have found secondary metabolites that can act as deterrents to predation across a wide variety of taxa such as seaweeds, sponges, ascidians, and corals (see reviews by Hay \& Fenical 1988, Pawlik 1993, Paul \& Puglisi 2004). In contrast, the prevalence of feeding-deterrent secondary metabolites in soft-substrate organisms appears to be much lower, although direct examinations of this are relatively rare (McClintock \& Baker 2001, Kicklighter et al. 2003). Although a variety of halogenated organics (e.g. bromo- and chlorophenols) have been isolated from a number of common soft-sediment infaunal polychaetes (Woodin 1985, Steward et al. 1996, Fielman et al. 1999, Kicklighter et al. 2003, 2004a,b), hemichordates (King 1986, King et al. 1995, Steward et al. 1996, Giray \& King 1997, Fielman et al. 1999, Cowart et al. 2000), and at least 1 mollusk (Fielman et al. 1999), evidence for their effectiveness as antipredator defenses is equivocal at best (Giray \& King 1997, Kicklighter et al. 2004b). Still, chemical deterrents against generalist predators have been demonstrated for a few soft-sediment invertebrates (Kicklighter et al. 2003, 2004b).

Given the large number of studies that have demonstrated the important structuring role of predators in 
soft-sediment communities (Botton 1984, Summerson \& Peterson 1984, Wilson 1990, Irlandi 1994, Micheli 1996, Thrush 1999, Grabowski \& Powers 2004) it seems unlikely that chemical defenses are uncommon in this habitat because of a lack of predation pressure. Indeed, other types of defenses, such as hard shells, are quite common among some infaunal taxa. Additionally, many soft-sediment organisms are mobile (e.g. polychaete worms) and can rely on rapid flight and burrowing to avoid predation, perhaps weakening selection for the production of defenses. Some softsediment organisms are effectively sessile, with very limited mobility, living inside permanent tubes that they build and occupy from metamorphosis throughout their adult life. It is in these organisms that one might expect selection for chemical defenses to be strongest (Kicklighter \& Hay 2007). We tested the role of chemical defenses in preventing predation on phoronids, one such group of organisms.

Phoronids are relatively large tube-building, lophophorate 'worms'. Phoronopsis viridis reaches high densities in northern Pacific Coast tidal flats, with 26500 ind. $\mathrm{m}^{-2}$ a common occurrence (A. A. Larson pers. obs.), and a maximum reported density of $150000 \mathrm{~m}^{-2}$ (Ronan 1978). Individuals build tubes that are 1 to $3 \mathrm{~mm}$ in diameter by $15 \mathrm{~cm}$ long. They extend their green lophophores and top portion of their trunk $\sim 1 \mathrm{~cm}$ above the sediment-water interface to feed. Despite their high abundance, they are rarely found in the guts of common predators (rays, birds, fishes) on tidal flats in Bodega Harbor, California, USA (Everett 1991, V. Estelle pers. comm., G. Ruiz unpubl. data, J. Hobbs \& L. Lewis unpubl. data).

In this study, we assessed the possibility that phoronids may attain such high densities because they are in whole or in part unpalatable to the suite of predators with which they co-occur. We also assessed the evidence that any unpalatability is caused by noxious chemicals. Specifically, we asked the following questions: (1) Is Phoronopsis viridis palatable to 5 common fishes and crabs? (2) Are different parts of the phoronid differentially palatable and does this correlate with the degree to which the unpalatable body parts are exposed to surface feeders? (3) Do phoronids contain chemical feeding deterrents to predation by common fishes and crabs? We also used these organisms as models to ask 2 more questions about the value of defenses for prey and consequences for predators that consume chemically defended prey. First, by simulating partial predation on exposed tissues, we asked what the potential costs of not being defended might be. Second, we asked whether predators that consume phoronids can learn to avoid phoronids when fed a diet that includes 1 to 3 phoronids $\mathrm{d}^{-1}$.

\section{MATERIALS AND METHODS}

Study organisms. In Bodega Harbor, and other bays in California, the phoronid studied has been called Phoronopsis viridis (Hilton 1930); it has been synonymized with $P$. harmeri (Pixell 1912) by Marsden (1959). Although currently considered the same species, the relationship appears uncertain; here we use the name $P$. viridis in the case that the northeastern Pacific populations are indeed distinct from the more cosmopolitan P. harmeri.

Palatability assays with phoronids were conducted at the Bodega Marine Laboratory during the summers of 2002, 2004, and 2007 (see below). Common predators were collected from or adjacent to the phoronid beds in Bodega Harbor and consisted of 2 fishes and $3 \mathrm{crab}$ species. All specimens used in this experiment were collected and maintained in accordance with institutional and national guidelines concerning the use of animals in research including use of approved permits and protocols. Where noted, we used juveniles rather than adults because in these species, the juveniles were more abundant because individuals move out of bays as adults. Juvenile striped seaperch Embiotoca lateralis consume prey items that are similar to those found in the Phoronopsis viridis beds, including polychaetes and gammarid amphipods (Alevizon 1975). Seaperch were kept in groups of 3 fish, each group in half of a divided 10 gallon ( $28 \mathrm{l}$ ) aquarium because they fed regularly and responded well to these conditions. One focal individual of each group of 3 fish was monitored and used as the replicate in each assay; other fish within the group were not used for that particular assay. Groups of fish were used in different assays after a hiatus of $2 \mathrm{~d}$ or more between assays. The next focal individual was haphazardly selected from the group of 3 fish. The tanks were kept with continuously flowing seawater and aeration, and fish were fed a diet of frozen brine shrimp (Sally's Frozen Brine Shrimp, San Francisco Bay Brand) enriched with a highly unsaturated fatty acid supplement, SELCO ${ }^{\odot}$ (from Brine Shrimp Direct), and sinking pellet food.

Juvenile cabezon Scorpaenichthys marmoratus are also common in seagrass beds and surrounding mudflats and readily try to consume any live invertebrate or artificial food offered in the laboratory. S. marmoratus were kept individually in perforated 2.371 plastic buckets in a flow-through seawater table. They were fed daily to satiation on a diet of squid paste and brine shrimp.

We also used 3 crab species that are known to consume infaunal prey. All crabs were kept individually in perforated 21 plastic buckets in a flow-through seawater table in the laboratory and maintained on a diet of defrosted frozen brine shrimp and small clams. The 
yellow shore crab Hemigrapsus oregonensis is the most common crab found on the tidal flats in Bodega Harbor and is opportunistically omnivorous (Ricketts et al. 1985). We used male crabs with a carapace width of $18 \pm 2.5 \mathrm{~mm}$ (mean $\pm \mathrm{SD}$ ). The European green crab Carcinus maenas is an introduced species of portunid crab that was first detected in Bodega Harbor in 1993 (Grosholz et al. 2000). Juvenile C. maenas (carapace width $27 \pm 4.7 \mathrm{~mm}$ ) were collected using pitfall traps. Juvenile red rock crab Cancer antennarius are seasonally abundant on the tidal flats. They are predators and scavengers (Morris et al. 1980). We used C. antennarius individuals that were approximately $20 \mathrm{~mm}$ in carapace width.

Palatability assays: general approach. Palatability of a prey item was assessed by comparing the frequency of its rejection to the frequency of rejection of control items known to be palatable to the predator in question. Controls consisted of either brine shrimp or squid paste, depending on the predator; these control foods were indistinguishable from phoronids based on percent organic content (A. A. Larson unpubl. data). Squid paste was made by homogenizing squid mantle flesh with an equal volume of deionized water and adding sodium alginate at $2 \%$ of the total wet mass. Predators were well fed approximately $1 \mathrm{~h}$ prior to running a palatability assay to standardize hunger level among individuals. Any remaining food was removed, and the tanks were cleaned before running an assay. Our palatability assays followed previously used protocols (Pawlik et al. 1995, Hay et al. 1998, Stachowicz \& Lindquist 2000). Predators were first offered a control of a palatable food to assess their willingness to feed. If the first control was consumed, then the predator was offered a test food item. Rejection was only considered to occur if the predator took the treatment item into its mouth and subsequently expelled it; ignoring a food item was not considered a rejection. The treatment was followed by a second control food item to test whether predators were satiated. Replicates in which the test food item and second control were rejected were discarded, as the predator could have rejected the test food item because it was satiated rather than because the test food item was unpalatable. Fisher's exact test was used to determine whether the number of test food items that were accepted by individual predators was statistically different from the number of controls that were accepted (fish always consumed the controls; Gotelli \& Ellison 2004).

Whole-organism palatability. Whole-organism palatability assays were conducted using $n=9$ to 27 individuals of each predator species depending upon availability of predators willing to consume prey under laboratory conditions. Phoronopsis viridis were collected in the field on the same day that assays were conducted. Once in the laboratory, they were carefully removed from their tubes. First, we conducted assays in which a whole phoronid was offered to each of the predators. Next, $P$. viridis individuals were separated into obvious distinct body sections, i.e. lophophore, trunk, and ampulla, and a $1 \mathrm{~cm}$ long piece of each section was offered individually to a predator to determine if palatability varies among parts of the individual that differ in their degree of exposure to predators (see 'Results' for an illustration of different body sections).

Chemical extract assays. Because phoronids and phoronid parts were consistently rejected by most predators (see 'Results'), we assessed the effect of phoronid chemical extracts on a subset of predators from the whole-organism assay: the fish Embiotoca lateralis and Scorpaenichthys marmoratus, and the crab Hemigrapsus oregonensis. Initially, we extracted whole phoronids in a volume of 2:1 methylene chloride $(\mathrm{DCM})$ and methanol $(\mathrm{MeOH})$ that was at least $15 \times$ the volume of phoronids. We then removed solvents by rotary evaporation. Because the results of these initial assays were variable and the pungent (non-solvent) odor emerging from the evaporator during the extraction suggested that we might be losing volatile compounds, we decided to reduce the volume of phoronid being extracted by selecting only the most deterrent body parts (the top $1 \mathrm{~cm}$, see 'Results') and used pentane, a more easily evaporated solvent that allowed us to obtain even moderately volatile compounds, in mixture with $\mathrm{MeOH}$ and water (4:4:1, MeOH:water: pentane at $5 \times$ the volume of the macerated phoronids). After homogenizing and mixing the Phoronopsis viridis tops with the solvent mixture, we allowed it to extract for at least $1 \mathrm{~h}$ in a sealed vial. We used an HPLC syringe to remove and set aside the pentane fraction that floated atop the water:MeOH fraction. This extraction was repeated until the solvents remained clear (2 to 4 times). The MeOH:water fraction was centrifuged to separate and remove phoronid body parts, and the solvents were removed by rotary evaporation. The pentane fraction was then added to the dried compounds from the $\mathrm{MeOH}$ :water fraction and allowed to evaporate until the total extract was dry (typically less than $1 \mathrm{~min}$ ). The combination of compounds extracted in the pentane and in the water: $\mathrm{MeOH}$ fractions yielded the total extract used to test for the presence of deterrent compounds. After testing the total extract, the lipid-soluble and water-soluble partitions of the extract were tested individually to isolate the observed feeding deterrent activity (see 'Results'). The extraction was conducted as above, but when the pentane fraction was removed, the 2 partitions were kept separately and dried to remove solvents. The water:MeOH fraction still required rotary evaporation, but the pentane fraction evaporated to 
dryness very quickly. For an additional test, we further removed very volatile or reactive compounds from the pentane fraction by allowing for a longer drying time (5 min after dryness was noted) before testing for palatability.

The dry extracts were tested for their effects on palatability by mixing them into a known palatable food (squid paste) at their natural volumetric concentration. Once the extracts were mixed into the squid paste, the mixture was loaded into a syringe and extruded into $0.25 \mathrm{M}$ calcium chloride solution, which caused the mixture to harden to the texture of cooked pasta. The cylindrical string of food was cut into bitesize pellets for the predators being assayed. Control foods were made using the same procedure except that no phoronid body parts were added to the solvent mixtures (Stachowicz \& Lindquist 2000).

Additional fractionation of the pentane fraction and subsequent bioassays were conducted using a cold distillation process to trap volatile compounds, followed by identification of compounds using thin layer chromatography and separation with a silica pencil column. We also tested the deterrent properties of 3 specific brominated phenolic compounds - 2,4-dibromophenol, 2,6-dibromophenol, and 2,4,6-tribromophenol-as these compounds have been previously suggested to be biologically active (Kicklighter et al. 2004b) and two have been reported from Phoronopsis viridis (Sheikh \& Djerassi 1975). We measured the concentration of these compounds in phoronids from Bodega Harbor using the following procedure. Two samples, one with 10 whole phoronids and a second with 20 phoronid lophophores, were extracted with $\mathrm{MeOH}$ :water:pentane as described above except that the tissues were kept in the solvents for $48 \mathrm{~h}$. The pentane fraction was then analyzed with a gas chromatograph/time of flight-mass spectrometer (GC/TOF-MS) to determine concentrations of all 3 bromophenols (Whitfield et al. 2002). We focused on the pentane fraction because this was the only fraction that exhibited activity in our bioassays (see 'Results'). Each compound was tested in separate feeding assays with seaperch by adding it to squid paste at concentrations that reflect whole phoronid and phoronid lophophore concentrations, where these could be detected by the GC/ TOF-MS, and at a range of higher concentrations. When the bromophenol compound was not detectable by GC/TOF-MS, it was offered to Embiotoca lateralis at concentrations found in other infaunal species as reported in the literature and at higher concentrations: 2,6 -dibromophenol is found at $2.84 \times 10^{-6} \mathrm{~g} \mathrm{ml}^{-1}$ in acorn worms Balanoglossus aurantiacus (Kicklighter et al. 2004b), and 2,4,6-tribromophenol is found at a concentration of $1.118 \times 10^{-5} \mathrm{~g} \mathrm{ml}^{-1}$ in $B$. carnosus (Higa et al. 1980). Feeding assays for the extracts and fractions were conducted using the standard palatability procedures described.

Lophophore regeneration: the cost of partial predation. Palatability assays suggested that chemical deterrence is concentrated in the lophophore (see 'Results'), the exposed portion of the individual responsible for food collection. To quantify the benefits of defending this vulnerable structure, we assessed how long it would take phoronids that had lost a lophophore to regenerate it and regain unpalatability. In June 2003, a $5 \times 5 \mathrm{~m}$ plot was established in Bodega Harbor. A square-head shovel was repeatedly pushed horizontally under the sediment surface, about 3 to $5 \mathrm{~cm}$ in depth throughout the $5 \times 5 \mathrm{~m}$ plot, just after the tidal ebb had exposed the sediment. This method effectively cut off the anterior portions of most of the phoronids within the plot while largely maintaining the sediment structure (there was some disturbance around the edges of the shovel) and leaving the tubes intact. Following the disturbance event, 1 to 3 cores were taken daily from haphazardly selected locations within the plot. Sampled sections were documented to prevent resampling locations. Phoronids were removed from the sediments and carefully extracted from their tubes. The top $1 \mathrm{~cm}$ of the phoronids were used in a feeding assay with the seaperch Embiotoca lateralis with brine shrimp as controls as described previously. Digital images were taken of anterior ends of individual phoronids and analyzed using ImageJ software. The lophophore on Phoronopsis viridis is a complex structure that consists of a ring of about 300 ciliated tentacle-like structures, all of similar length. The ring is folded in on itself in 2 inward-facing spirals. The lophophore size was measured by taking an average of the distances from the base (just above the collar) to the distal tip of the lophophore at 4 locations, 2 laterally and 2 medially. The trial ran until the lophophore size in the manipulated plot approached the average lophophore size of adjacent unmanipulated individuals and all of the treatments were consistently rejected by the predators.

Learning in Scorpaenichthys marmoratus. S. marmoratus initially consumed a high percentage of the tissue treatments and extracts, suggesting that it is unable to recognize this deterrent or is unaffected by it (see 'Results'). However, sculpins exhibited anomalous behavior after consuming a phoronid, including flaring of gills, regurgitation, head shaking, and darkening of skin pigmentation, indicating some negative response. To test whether $S$. marmoratus could learn to avoid or reject Phoronopsis viridis over time, groups of 10 juveniles were fed $0,1,2$, or 3 phoronids $\mathrm{d}^{-1}$ over $48 \mathrm{~d}$ (Table 1). Treatments were randomly assigned to individual fish at the beginning of the experiment. All treatment groups of fish received a meal of brine 
Table 1. Scorpaenichthys marmoratus. Feeding schedule where the 'phoronid' feeding consisted of fish being offered a brine shrimp, followed by a phoronid, followed by another brine shrimp to assess satiation. Rejection or acceptance of the phoronid was noted. 'Control' feedings consist of a volume of brine shrimp equivalent to the volume of the 'phoronid' meal. Feedings occurred at 2 to $2.5 \mathrm{~h}$ intervals after an initial maintenance meal between 09:00 and 10:00 h of brine shrimp and squid paste for all groups

\begin{tabular}{|lccc|}
\hline Group & 1st feeding & 2nd feeding & 3rd feeding \\
\hline 0 & Control & Control & Control \\
1 & Phoronid & Control & Control \\
2 & Phoronid & Phoronid & Control \\
3 & Phoronid & Phoronid & Phoronid \\
\hline
\end{tabular}

shrimp and squid paste tinted with food coloring between 09:00 and 10:00 h each day. All fish were offered 1 phoronid on the first day of the study along with a brine shrimp control to assess baseline levels of rejection. Subsequent feedings occurred at 2 to $2.5 \mathrm{~h}$ intervals. All fish received the same volume of food (approximately $0.15 \mathrm{~cm}^{3}$ per feeding, including controls), so their diet varied only in the number of phoronids they consumed each day. At the end of each meal, fish that rejected $P$. viridis received an equivalent volume $\left(0.05 \mathrm{~cm}^{3}\right)$ of brine shrimp to ensure that all fish had the same volume of food available for consumption throughout the experiment. The assay was run until all treatment groups maintained a consistent rate of prey rejection for at least $3 \mathrm{~d}$ (established a priori). After $48 \mathrm{~d}$, all groups $\left(0,1,2\right.$, and $3 P$. viridis $\left.\mathrm{d}^{-1}\right)$ were used in a feeding assay (with before and after brine shrimp controls) where a $P$. viridis was used as the treatment for all groups.

\section{RESULTS}

\section{Whole-organism palatability}

Phoronopsis viridis tissue assays indicated that the whole organism and especially the lophophore portion was less palatable to all 5 predators than control foods ( $\mathrm{p} \leq 0.012$, Table 2). Relative acceptance levels varied: acceptance levels were at $0 \%$ or very low for Carcinus maenas, Hemigrapsus oregonensis, and Embiotoca lateralis, whereas Scorpaenichthys marmoratus and Cancer antennarius had higher consumption of whole $P$. viridis. S. marmoratus and C. antennarius also showed comparatively high consumption of the lophophore (26.7 and $53.3 \%$, respectively), whereas the other predators rarely consumed the lophophore section. Three of the predators (C. antennarius, E. lateralis, and $S$. marmoratus) readily consumed both the trunk and the ampulla at proportions equal to controls ( $p \geq 0.087$ ). The trunk and the ampulla were unpalatable to $H$. oregonensis and $C$. maenas, and few individuals con-

Table 2. Phoronopsis viridis tissues consumed by 5 predators. Percent of individuals that consumed the treatments, total number (n) of predators used for each assay, and p-values (generated from Fisher's exact test) are shown

\begin{tabular}{|c|c|c|c|c|c|}
\hline & $\begin{array}{l}\text { Shore crab } \\
\text { Hemigrapsus } \\
\text { oregonensis }\end{array}$ & $\begin{array}{l}\text { European green crab } \\
\text { Carcinus } \\
\text { maenas }\end{array}$ & $\begin{array}{c}\text { Red rock crab } \\
\text { Cancer } \\
\text { antennarius }\end{array}$ & $\begin{array}{c}\text { Striped seaperch } \\
\text { Embiotoca } \\
\text { lateralis }\end{array}$ & $\begin{array}{l}\text { Cabezon } \\
\text { Scorpaenichthys } \\
\text { marmoratus }\end{array}$ \\
\hline Whole organism & $\begin{array}{c}0 \% \\
\mathrm{n}=15 \\
\mathrm{p}<0.001\end{array}$ & $\begin{array}{c}0 \% \\
n=9 \\
p<0.001\end{array}$ & $\begin{array}{c}45.5 \% \\
n=11 \\
p=0.012\end{array}$ & $\begin{array}{c}20 \% \\
\mathrm{n}=15 \\
\mathrm{p}<0.001\end{array}$ & $\begin{array}{c}72 \% \\
n=25 \\
p=0.01\end{array}$ \\
\hline Lophophore & $\begin{array}{c}16.7 \% \\
n=12 \\
p<0.001\end{array}$ & $\begin{array}{c}0 \% \\
\mathrm{n}=20 \\
\mathrm{p}<0.001\end{array}$ & $\begin{array}{c}53.3 \% \\
n=15 \\
p=0.006\end{array}$ & $\begin{array}{c}6.7 \% \\
n=15 \\
p<0.001\end{array}$ & $\begin{array}{c}26.7 \% \\
\mathrm{n}=15 \\
\mathrm{p}<0.001\end{array}$ \\
\hline Trunk & $\begin{array}{c}23.5 \% \\
\mathrm{n}=17 \\
\mathrm{p}<0.001\end{array}$ & $\begin{array}{c}0 \% \\
\mathrm{n}=19 \\
\mathrm{p}<0.001\end{array}$ & $\begin{array}{c}60 \% \\
n=10 \\
p=0.087\end{array}$ & $\begin{array}{c}92.9 \% \\
n=14 \\
p=0.99\end{array}$ & $\begin{array}{c}96.2 \% \\
n=27 \\
p=0.99\end{array}$ \\
\hline Ampulla & $\begin{array}{c}15.4 \% \\
\mathrm{n}=13 \\
\mathrm{p}<0.001\end{array}$ & $\begin{array}{c}68.4 \% \\
\mathrm{n}=19 \\
\mathrm{p}=0.02\end{array}$ & $\begin{array}{c}70 \% \\
\mathrm{n}=10 \\
\mathrm{p}=0.211\end{array}$ & $\begin{array}{c}100 \% \\
\mathrm{n}=15 \\
\mathrm{p}=1\end{array}$ & $\begin{array}{c}93.3 \% \\
\mathrm{n}=15 \\
\mathrm{p}=0.99\end{array}$ \\
\hline
\end{tabular}


sumed these treatments when compared to controls ( $\mathrm{p}$ $<0.001$ ), with the exception of $68 \%$ of $C$. maenas that consumed the ampulla ( $\mathrm{n}=19, \mathrm{p}=0.02$; Table 2 ).

\section{Chemical extract assays}

The effects of the extracts that were tested on a subset of the predators used in the whole-tissue study indicate that the deterrent effect is, at least in part, chemically mediated. Crude extracts of the whole phoronids reduced feeding by Hemigrapsus oregonensis and Embiotoca lateralis by $37 \%$ (Fisher's exact test, p =
0.004 and $p=0.09$, respectively; Fig. 1A,B), much less than the rejection rates of the whole organisms (80 to $100 \%$ ) by these predators (Table 2). This crude extract was palatable to Scorpaenichthys marmoratus (84\% acceptance, Fig. 1C). However, the crude extract required a slightly longer drying time after the pentane fraction was combined with the dry MeOH:water extracts, so the possibility of loss of volatile compounds could explain the lower rates of rejection relative to whole organisms. When we assayed the pentanesoluble fraction alone (which required only brief drying) it reduced feeding by $H$. oregonensis and E. lateralis by $90 \%$ ( $<0.001$ for both, Fig. 1A,B). All S. mar-
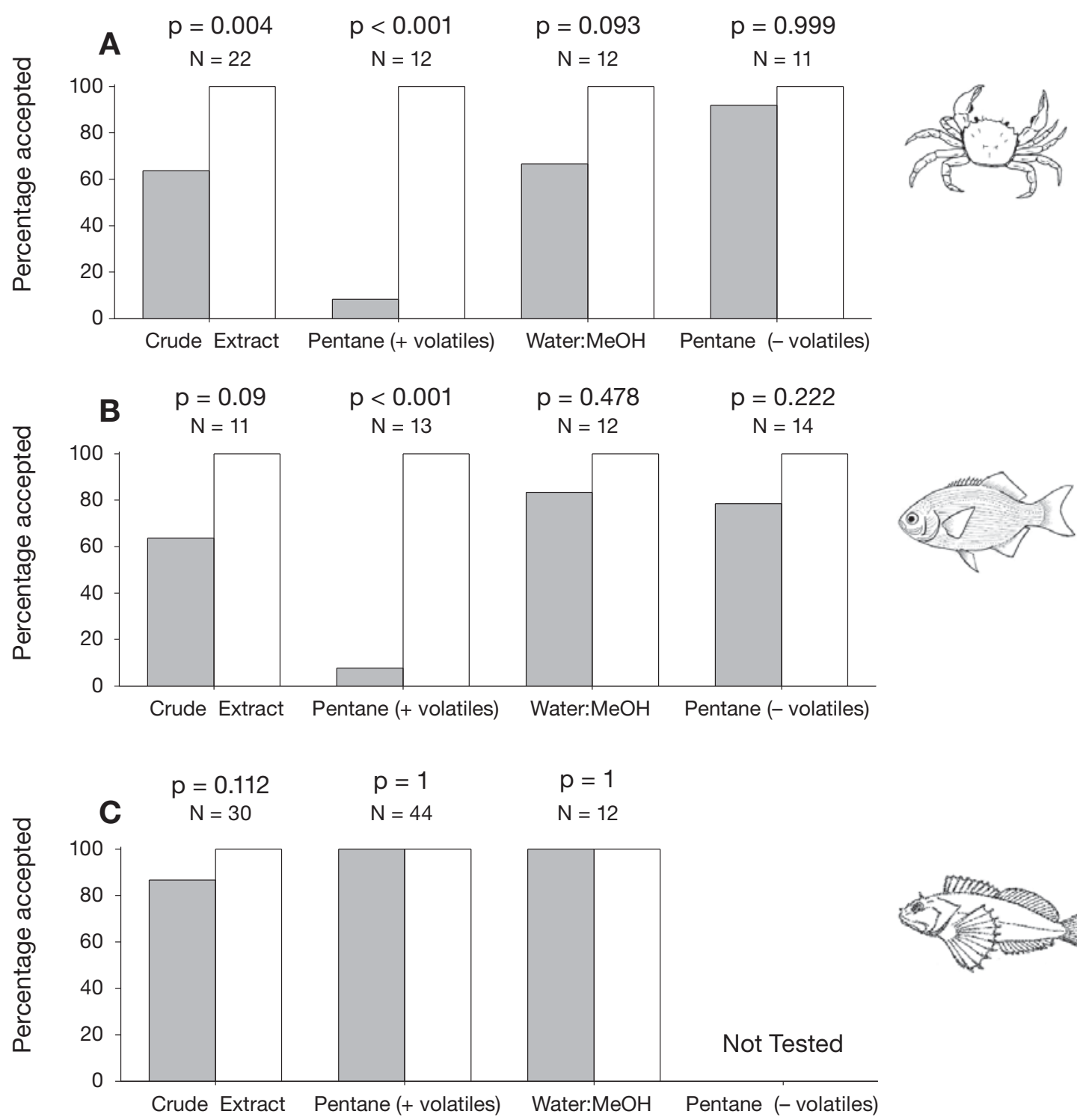

Fig. 1. Hemigrapsus oregonensis, Embiotoca lateralis and Scorpaenichthys marmoratus. Palatability assays of Phoronopsis viridis extracts to (A) the shore crab H. oregonensis, (B) the striped seaperch E. lateralis, and (C) the cabezon S. marmoratus. Percentage of individual predators that consumed extracts incorporated into squid paste (grey bars) and palatable control squid paste (open bars) are presented. p-values were determined by Fisher's exact test 
moratus still consumed foods with the pentane-soluble fraction ( $p=1.0$, Fig. $1 \mathrm{C}$ ), in agreement with their high acceptance rate of intact organisms (72\% consumed whole Phoronopsis viridis; see Table 2). Water:MeOH fractions did not have an effect on feeding by any of the consumers (Fig. 1). When the pentane fraction was left for 5 min after complete evaporation of the solvent, the remaining residue did not affect feeding by either predator $(H$. oregonensis or E. lateralis), suggesting that the deterrent compound(s) are volatile and/or reactive with air.

Bioassay guided fractionation of the pentane fraction failed to isolate a specific deterrent compound, as activity was lost with additional fractionation beyond the pentane partition. However, when assayed for specific bromophenol compounds thought to affect palatability, GC/TOF-MS analysis showed that Phoronopsis viridis contains 2,4-dibromophenol at a concentration of $3.91 \times 10^{-5} \mathrm{~g} \mathrm{ml}^{-1}$ wet tissue $\left(=6.25 \times 10^{-6} \mathrm{~g} \mathrm{~g}^{-1}\right.$ dry weight) in whole phoronids, and $2.14 \times 10^{-4} \mathrm{~g} \mathrm{ml}^{-1}$ wet tissue $\left(=6.12 \times 10^{-5} \mathrm{~g} \mathrm{~g} \mathrm{~g}^{-1}\right.$ dry weight) in the lophophore only. 2,4-dibromophenol had not previously been reported for $P$. viridis and was not deterrent to Embiotoca lateralis at either the whole-organism or lophophore concentration. However, E. lateralis did begin to reject the treatments at a concentration of $2.82 \times 10^{-3} \mathrm{~g}$ $\mathrm{ml}^{-1}$ wet tissue and higher (or greater than $72 \times$ whole phoronid concentration and $13 \times$ lophophore concentration; Fig. 2). As GC/TOF-MS could not detect the presence of 2,4,6-tribromophenol or 2,6-dibromophenol in our phoronids, it is possible that the latter 2 compounds occurred at concentrations $<5 \mu \mathrm{g} \mathrm{ml} \mathrm{m}^{-1}$. Addition of 2,6-dibromophenol and 2,4,6-tribromophenol compounds to squid paste did not deter E. lateralis, which consumed $100 \%$ of each treatment at all concentrations tested for 2,6-dibromophenol and 2,4,6-tribromophenol ( $\mathrm{n}=11$ to 15 ); 2,6-dibromophenol was tested at $2.84 \times 10^{-6}, 3.91 \times 10^{-5}, 5.68 \times 10^{-5}$, $2.14 \times 10^{-4}$, and $2.84 \times 10^{-3} \mathrm{~g} \mathrm{ml}^{-1}$ wet tissue (or $1 \times$, $138 \times, 200 \times, 754 \times$, and $1000 \times$ values reported by Kicklighter et al. 2004b for Balanoglossus aurantiacus); and $2,4,6$-tribromophenol was tested at $1.1183 \times 10^{-5}$ and $2.24 \times 10^{-4} \mathrm{~g} \mathrm{ml}^{-1}$ wet tissue (or $1 \times$ and $20 \times$ concentrations reported for B. carnosus by Higa et al. 1980).

\section{Lophophore regeneration}

Phoronopsis viridis were generally palatable to 85$100 \%$ of Embiotoca lateralis during the first $10 \mathrm{~d}$ after removal of their anterior sections. No lophophore regrowth was observed until Day 6 (Fig. 3). After $11 \mathrm{~d}$, $P$. viridis lophophores regenerated to $1.3 \mathrm{~mm} \mathrm{(50 \% \text {of }}$ full size: $2.6 \pm 0.15 \mathrm{~mm}$ ), and E. lateralis consistently began to reject $P$. viridis at this stage. There was a dra-

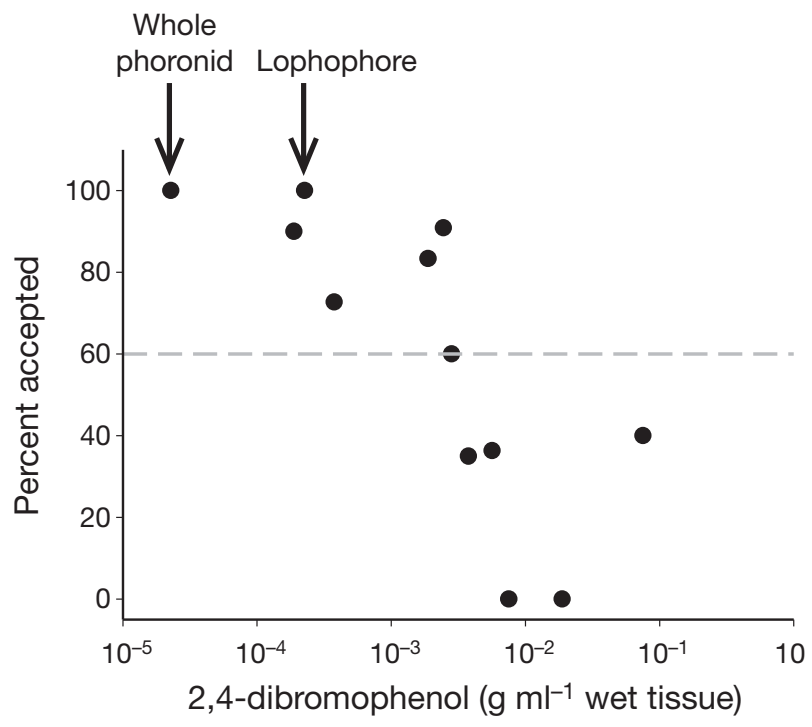

Fig. 2. Embiotoca lateralis. Dose response for 2,4-dibromophenol. The percent of individual E. lateralis $(n=15)$ that consumed treatments of squid paste containing different concentrations of 2,4-dibromophenol. At and below the dashed line, the p-values from Fisher's exact test were $\leq 0.01$, above the line $p \geq 0.214$. Arrows indicate the concentrations of 2,4-dibromophenol that were found in whole phoronids and the phoronid lophophore

matic increase in the number of phoronids that were rejected between Day 11 (29\%) and Day 12 (86\%) after the tops of the lophophores were removed. Sixteen days after the tops of $P$. viridis were removed, lophophore lengths approached the size of unmanipulated populations, and they elicited a rejection in $100 \%$ of E. lateralis.

\section{Learning assay}

The frequency of rejection of phoronids by Scorpaenichthys marmoratus increased for fish raised on a diet that included phoronids, with the magnitude of the response generally increasing with increasing numbers of phoronids in the diet (Fig. 4A). During several periods throughout the experiment, rejection frequency of fish fed 2 and 3 phoronids $\mathrm{d}^{-1}$ increased, then declined back to control levels (e.g. Days 4 to 5 and 20 to 25, Fig. 4A). We used 3 d running averages to smooth daily variation and to better follow the trajectories of the different treatments. At the end of the $48 \mathrm{~d}$ experiment, fish fed 2 or 3 Phoronopsis viridis $\mathrm{d}^{-1}$ were 3 to 5 times more likely to reject $P$. viridis than $S$. marmoratus that were kept on a diet of brine shrimp alone (Fig. 4B, p = 0.035 and 0.018, respectively). The experiment was ended after $48 \mathrm{~d}$ because the results appeared to stabilize, and many of the fish fed 3 phoronids $d^{-1}$ ceased feeding altogether (in- 


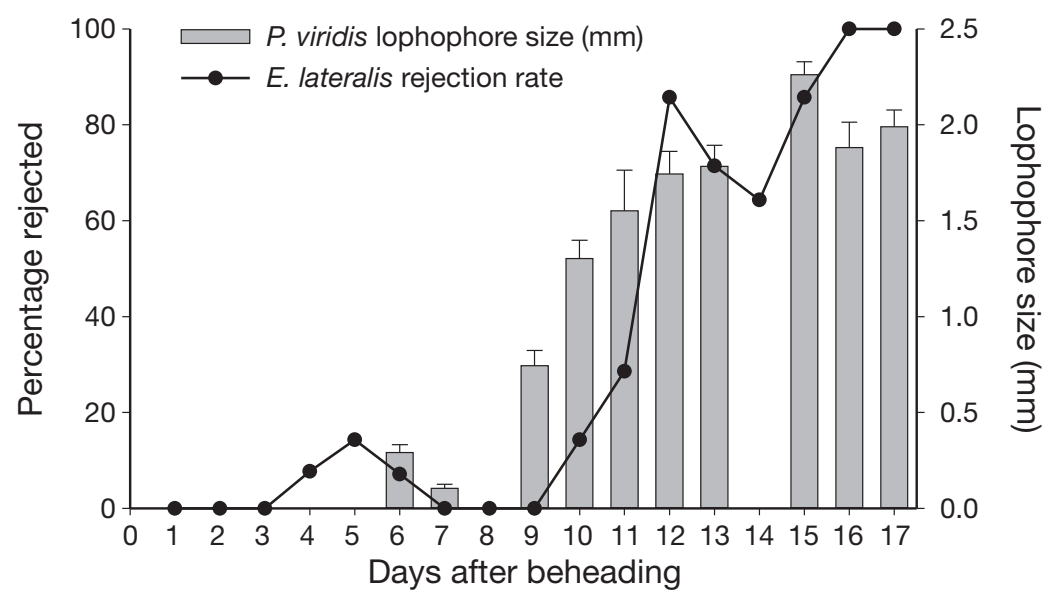

Fig. 3. Phoronopsis viridis and Embiotoca lateralis. Palatability of regenerated phoronid lophophores to E. lateralis. Grey bars indicate the average regenerated lophophore size \pm SE ( $\mathrm{n}=13$ to 26$)$ of $P$. viridis each day after removal in the field. The blank field at Day 14 indicates no data, all other blank fields indicate $0 \mathrm{~mm}$ lophophore. Black dots represent the percentage of E. lateralis $(\mathrm{n}=16)$ that rejected the $P$. viridis offered each day

A
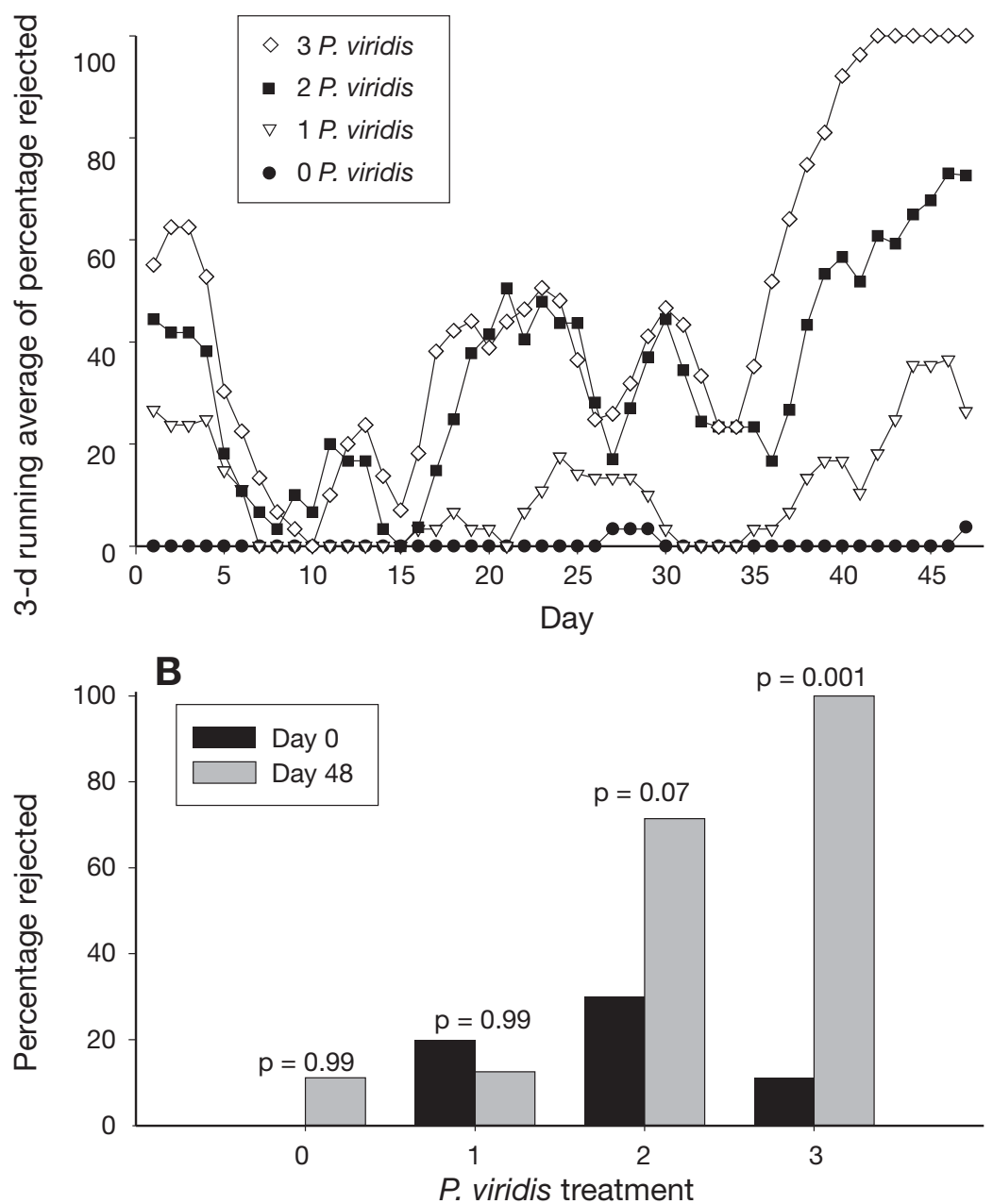

cluding controls). S. marmoratus that received 0 or $1 P$. viridis $\mathrm{d}^{-1}$ were as likely to reject a $P$. viridis treatment at the end as they were at the outset of the experiment (Fig. 4B, $p=0.99$ for both).

\section{DISCUSSION}

Phoronopsis viridis strongly deters predation by a number of local generalist feeders, including $3 \mathrm{crab}$ species and 2 fishes. This deterrent ability is most concentrated in their lophophore and in the top portion of their trunk, although all body parts exhibited deterrent activity in at least some of the predators used. This deterrent effect can be attributed at least in part to non-polar compound(s) that may be volatile, or decompose quickly in air. Chemical defenses cause over a $90 \%$ decrease in consumption by the crab Hemigrapsus oregonensis and the fish Embiotoca lateralis. The cabezon Scorpaenichthys marmoratus was not as strongly deterred as the other species, but these fish did show signs (other than rejection), including regurgitation, darkening in color, and learned avoidance, suggesting that $P$. viridis and its associated compounds have potentially negative effects.

Despite an overall pattern of unpalatability, there were some differences in the responses of predators to phoronids. The green crab Carcinus maenas, a recent invader to Bodega Harbor known to have large effects on the infaunal community (Grosholz et al. 2000), was the most sensitive of the predator species tested, con-

Fig. 4. Scorpaenichthys marmoratus. Learning assay conducted with juveniles that were fed $0,1,2$, or 3 phoronids daily for $48 \mathrm{~d}$. (A) Three day running average of percentage of the fish that rejected treatments during the first time a Phoronopsis viridis treatment (of 3 ) was offered. Fish receiving 1, 2, or $3 P$. viridis $\mathrm{d}^{-1}$ all received $P$. viridis, whereas fish receiving $0 P$. viridis $\mathrm{d}^{-1}$ were fed $0.05 \mathrm{~cm}^{3}$ brine shrimp. (B) Fish from all treatment groups that rejected $1 P$. viridis at the initiation (Day 0) and at the end (Day 48) of the trial. p-values were calculated using Fisher's exact test 
suming none of the whole organism, lophophore, or trunk treatments. Scorpaenichthys marmoratus consumed intact worms much more frequently than did other predators. This may be related to their feeding mode: these fish rapidly swallow food whole, which may prevent the 'tasting' of prey needed for rejection. In contrast, Embiotoca lateralis and the crabs that did reject Phoronopsis viridis tend to sample and masticate food offered before ingesting, leading to more opportunity for rejection of prey. However, all predators differentiated between the anterior and posterior portions, finding parts that are typically concealed in tubes more palatable than the lophophore. Furthermore, S. marmoratus ultimately learned to reject $P$. viridis as part of their diet. As we did not expect $S$. marmoratus to have such variable rejection rates on a day to day basis, and did not anticipate that this experiment would last for $48 \mathrm{~d}$, we did not quantify changes in fish size or mass over the course of the experiment and are unable to directly assess the costs of compound ingestion on fitness. Other studies using a similar design have shown an association between the ingestion of ecologically relevant quantities of a noxious compound and reduced fitness of a predator that did not learn to avoid chemically defended food (Lindquist \& Hay 1995).

For the prey, this study illustrates the costs of partial predation that would result from not being defended, and thus the strong selection for defense of exposed portions of the individual. Simulating predation on anterior portions of phoronids resulted in the loss of viable feeding structures for over $11 \mathrm{~d}$. Only once lophophore in the 'beheaded' treatment approached the size of control lophophores did the individual regain its unpalatabilty, suggesting either that defenses are not deployed until the body part is vulnerable again, or that normal feeding is required before defenses can be produced. Predation rates on exposed palatable organisms in mudflats can be high (Kneib \& Stiven 1982, Botton 1984, Wilson 1990, 1991, Lindsay et al. 1996, Hentschel \& Harper 2006), and thus the ability of phoronids to feed without this chemical deterrent would be reduced by either frequent loss of the lophophore or a need to frequently retract it to avoid predation (Peterson \& Skilleter 1994, Irlandi \& Mehlich 1996, Hentschel \& Harper 2006).

The compound that acts as a deterrent has been difficult to isolate in Phoronopsis viridis because of its volatility or reactivity with air. Two bromophenols $(2,4,6$ tribromophenol and 2,6-dibromophenol) were isolated from $P$. viridis by Sheikh \& Djerassi (1975) and hypothesized to function as feeding deterrents or to have antiseptic properties. Our data suggest that $P$. viridis contains 2,4-dibromophenol, and if present, the 2,6-dibromophenol and 2,4,6-tribromophenol are only present at very low concentrations $\left(<5 \mu \mathrm{g} \mathrm{ml}^{-1}\right)$ or were not extracted using our methods. 2,4-dibromophenol did not act as a predator deterrent at the concentrations found in phoronids or in phoronid lophophores. Neither 2,4,6-tribromophenol nor 2,6-dibromophenol was found to deter epibenthic predation. However, 2,4-dibromophenol and 2,4,6-tribromophenol have been shown to reduce settlement in sediments containing these compounds (Woodin et al. 1997), so the presence of 2,4-dibromophenol in phoronids still could play a role in allowing these individuals to achieve high densities. Although the number of soft-sediment invertebrates that have been shown to have a chemical deterrent to predators is increasing (Davis 1991, McClintock \& Baker 1997, Amsler et al. 2001, Benkendorff et al. 2001, Gaston \& Slattery 2002, Kicklighter et al. 2003, Kicklighter \& Hay 2006), few of these efforts have been successful at isolating the specific compound(s) responsible, suggesting that volatile or reactive compounds may be a common feature of chemically defended softsediment invertebrates across many phylogenetically distinct groups (e.g. lophophorates, annelids, and hemichordates). The reasons for such similarities in the structure or composition of these defenses across phylogenetically independent groups are unclear. Broad surveys of infaunal palatability suggest that chemically mediated predator deterrents are generally uncommon, particularly in unconsolidated sediments at temperate latitudes (Kicklighter \& Hay 2006), such as the tidal flats in Bodega Harbor. Thus P. viridis seems unusual in this regard. The relative rarity of chemical defenses in infaunal communities does not mean they are not important in structuring these communities.

Acknowledgements. We acknowledge and thank S. C. Lievens, T. F. Molinski, V. Tolstikov, R. Alvarado, and N. Lindquist for assistance with chemical extractions and attempts to isolate compounds found in the phoronids. For help collecting predators, we thank J. Hobbs and L. Lewis. Comments by B. T. Hentschel, N. Lindquist, and 2 anonymous reviewers improved this manuscript. Thanks also to M. Evans for enduring assistance in the field and laboratory and B. Steves for the illustrations. We are grateful for financial support provided by a National Science Foundation (NSF) Biological Oceanography Grant OCE 00-82049 to J.J.S. and funds to A.A.L. from the Joint Doctoral Program in Ecology at San Diego State University. For use of laboratory facilities as well as support of the staff, we gratefully acknowledge the Bodega Marine Laboratory.

\section{LITERATURE CITED}

Alevizon WS (1975) Comparative feeding ecology of a kelpbed embiotocid (Embiotoca lateralis). Copeia 1975:608-614

Amsler CD, McClintock JB, Baker BJ (2001) Secondary metabolites as mediators of trophic interactions among Antarctic marine organisms. Am Zool 41:17-26

> Benkendorff K, Davis AR, Bremner J (2001) Chemical defense in the egg masses of benthic invertebrates: an assessment 
of antibacterial activity in 39 mollusks and 4 polychaetes. J Invertebr Pathol 78:109-118

Botton ML (1984) The importance of predation by horseshoe crabs, Limulus polyphemus, to an intertidal sand flat community. J Mar Res 42:139-161

Cowart JD, Fielman KT, Woodin SA, Lincoln DE (2000) Halogenated metabolites in two marine polychaetes and their planktotrophic and lecithotrophic larvae. Mar Biol 136: 993-1002

Davis AR (1991) Alkaloids and ascidian chemical defenseevidence for the ecological role of natural products from Eudistoma olivaceum. Mar Biol 111:375-379

Everett RA (1991) Intertidal distribution of infauna in a central California lagoon: the role of seasonal blooms of microalgae. J Exp Mar Biol Ecol 150:223-247

> Fielman KT, Woodin SA, Walla MD, Lincoln DE (1999) Widespread occurrence of natural halogenated organics among temperate marine infauna. Mar Ecol Prog Ser 181:1-12

Gaston GR, Slattery M (2002) Ecological function of chemical deterrents in a tropical polychaete, Eupolymnia crassicornis (Annelida, Terebellidae), in Belize. Bull Mar Sci 70: 891-897

- Giray C, King GM (1997) Predator deterrence and 2,4-dibromophenol conservation by the enteropneusts Saccoglossus bromophenolosus and Protoglossus graveolens. Mar Ecol Prog Ser 159:229-238

Gotelli NJ, Ellison AM (2004) A primer of ecological statistics. Sinauer Associates, Sunderland, MA

- Grabowski J, Powers S (2004) Habitat complexity mitigates trophic transfer on oyster reefs. Mar Ecol Prog Ser 277: 291-295

Grosholz E, Ruiz GM, Dean CA, Shirley KA, Maron JL, Connors PG (2000) The impacts of a nonindigenous marine predator in a California bay. Ecology 8:1206-1224

Hay ME, Fenical W (1988) Marine plant-herbivore interactions - the ecology of chemical defense. Annu Rev Ecol Syst 19:111-145

Hay ME, Stachowicz JJ, Cruz-Rivera E, Bullard SG, Deal M, Lindquist N (1998) Bioassays with marine and freshwater macroorganisms. In: Haynes K, Millar J (eds) Methods in chemical ecology, Vol 2. Chapman \& Hall, New York, p 39-141

Hentschel BT, Harper NS (2006) Effects of simulated sublethal predation on the growth and regeneration rates of a spionid polychaete in laboratory flumes. Mar Biol 149: $1175-1183$

Higa T, Fujiyama T, Scheuer PJ (1980) Halogenated phenol and indole constituents of acorn worms. Comp Biochem Physiol B Biochem Mol Biol 65:525-530

Hilton WA (1930) Phoronidea from the coast of southern California. J Entomol Zool 22:33-35

Irlandi EA (1994) Large- and small-scale effects of habitat structure on rates of predation: how percent coverage of seagrass affects rates of predation and siphon nipping on an infaunal bivalve. Oecologia 98:176-183

Irlandi EA, Mehlich M (1996) The effect of tissue cropping and disturbance by browsing fishes on growth of two species of suspension-feeding bivalves. J Exp Mar Biol Ecol 197:279-293

Kicklighter CE, Hay ME (2006) Integrating prey defensive traits: contrasts of marine worms from temperate and tropical habitats. Ecol Monogr 76:195-215

Kicklighter CE, Hay ME (2007) To avoid or deter: interactions among defensive and escape strategies in sabellid worms. Oecologia 151:161-173

Kicklighter CE, Kubanek J, Barsby T, Hay ME (2003) Palatability and defense of some tropical infaunal worms: alkyl- pyrrole sulfamates as deterrents to fish feeding. Mar Ecol Prog Ser 263:299-306

Kicklighter CE, Fisher CR, Hay ME (2004a) Chemical defense of hydrothermal vent and hydrocarbon seep organisms: a preliminary assessment using shallow-water consumers. Mar Ecol Prog Ser 275:11-19

Kicklighter CE, Kubanek J, Hay ME (2004b) Do brominated natural products defend worms from consumers? Some do, most don't. Limnol Oceanogr 49:430-441

King GM (1986) Inhibition of microbial activity in marine sediments by a bromophenol from a hemichordate. Nature 323:257-259

King GM, Giray C, Kornfield I (1995) Biogeographical, biochemical and genetic differentiation among North American saccoglossids (Hemichordata; Enteropneusta; Harrimaniidae). Mar Biol 123:369-377

Kneib RT, Stiven AE (1982) Benthic invertebrate responses to size and density manipulations of the common mummichog, Fundulus heteroclitus, in an intertidal salt marsh. Ecology 63:1518-1532

> Lindquist N, Hay M (1995) Can small rare prey be chemically defended? The case for marine larvae. Ecology 76 : $1347-1358$

Lindsay SM, Wethey DS, Woodin SA (1996) Modeling interactions of browsing predation, infaunal activity, and recruitment in marine soft-sediment habitats. Am Nat 148: 684-699

Marsden JR (1959) Phoronidea from the Pacific coast of North America. Can J Zool 37:87-111

McClintock JB, Baker BJ (1997) A review of the chemical ecology of Antarctic marine invertebrates. Am Zool 37: 329-342

McClintock JB, Baker BJ (eds) (2001) Marine chemical ecology. CRC Press, Boca Raton, FL

Micheli F (1996) Predation intensity in estuarine soft bottoms: between-habitat comparisons and experimental artifacts. Mar Ecol Prog Ser 141:295-302

Morris RH, Abbott DP, Haderlie EC (1980) Intertidal invertebrates of California. Stanford University Press, Stanford, CA

> Paul VJ, Puglisi MP (2004) Chemical mediation of interactions among marine organisms. Nat Prod Rep 21:189-209

> Pawlik JR (1993) Marine invertebrate chemical defenses. Chem Rev 93:1911-1922

> Pawlik JR, Chanas B, Toonen RJ, Fenical W (1995) Defenses of Caribbean sponges against predatory reef fish. 1. Chemical deterrency. Mar Ecol Prog Ser 127:183-194

> Peterson CH, Skilleter GA (1994) Control of foraging behavior of individuals within an ecosystem context: the clam Macoma balthica, flow environment, and siphon-cropping fishes. Oecologia 100:256-267

Pixell HLM (1912) Two new species of the Phoronidea from Vancouver Island. Q J Microsc Sci 58:257-284

Ricketts EF, Calvin J, Hedgpeth JW, Phillips DW (1985) Between Pacific tides, 5th edn. Stanford University Press, Stanford, CA

> Ronan TE Jr (1978) Food-resources and the influence of spatial patterns on feeding in the phoronid Phoronopsis viridis. Biol Bull 154:472-484

Sheikh YM, Djerassi C (1975) 2,6-Dibromophenol and 2,4,6tribromophenols - antiseptic secondary metabolites of Phoronopsis viridis. Experientia 31:265-266

Stachowicz JJ, Lindquist N (2000) Hydroid defenses against predators: the importance of secondary metabolites versus nematocysts. Oecologia 124:280-288

Steward CC, Nold SC, Ringelberg DB, White DC, Lovell CR (1996) Microbial biomass and community structures in the 
burrows of bromophenol producing and non-producing marine worms and the surrounding sediments. Mar Ecol Prog Ser 133:149-165

Summerson HC, Peterson CH (1984) Role of predation in organizing benthic communities of a temperate-zone seagrass bed. Mar Ecol Prog Ser 15:63-77

> Thrush SE (1999) Complex role of predators in structuring soft-sediment macrobenthic communities: implications of changes in spatial scale for experimental studies. Aust J Ecol 24:344-354

Whitfield FB, Helidoniotis F, Smith D (2002) Role of feed ingredients in the bromophenol content of cultured prawns. Food Chem 79:355-365

Editorial responsibility: Joseph Pawlik, Wilmington, North Carolina, USA
Wilson WH (1990) Competition and predation in marine softsediment communities. Annu Rev Ecol Syst 21:221-241

Wilson WH (1991) The foraging ecology of migratory shorebirds in marine soft-sediment communities - the effects of episodic predation on prey populations. Am Zool 31: 840-848

Woodin SA (1985) Effects of defecation by arenicolid polychaete adults on spionid polychaete juveniles in field experiments: selective settlement or differential mortality. J Exp Mar Biol Ecol 87:119-132

Woodin SA, Lindsay SM, Lincoln DE (1997) Biogenic bromophenols as negative recruitment cues. Mar Ecol Prog Ser 157:303-306

Submitted: December 11, 2007; Accepted: October 1, 2008 Proofs received from author(s): December 12, 2008 